by Marie-Pierre Aubry ${ }^{\text {, Werner E. Piller }}{ }^{2 *}$, Philip L. Gibbard ${ }^{3}$, David A. T. Harper ${ }^{4}$, and Stanley C. Finney ${ }^{5}$

\title{
Ratification of subseries/subepochs as formal rank/units in international chronostratigraphy
}

\author{
${ }^{1}$ Department of Earth and Planetary Sciences, Rutgers University, Piscataway, NJ 08873, USA \\ ${ }^{2}$ Institute of Earth Sciences, University of Graz, NAWI Graz Geocenter, Heinrichstrasse 26, 8010 Graz, Austria; *Corresponding author: \\ E-mail:werner.piller@uni-graz.at \\ ${ }^{3}$ Scott Polar Research Institute, University of Cambridge, Lensfield Road, Cambridge CB2 1ER, UK \\ ${ }^{4}$ Department of Earth Sciences, Durham University, Durham DH1 3LE, UK \\ ${ }^{5}$ Department of Geological Sciences, California State University, Long Beach, USA
}

(Received: May 27, 2021; Revised accepted: July 8, 2021)

https://doi.org/10.18814/epiiugs/2021/021016

The IUGS Executive Committee has voted unanimously to ratify the proposal for formal adoption of the chronostratigraphical/geochronological unit divisions subseries/subepoch within the International Stratigraphic Guide as approved by the International Commission on Stratigraphy and forwarded to the IUGS EC on 24 March $2021^{* *}$. The subseries/subepochs are now incorporated in a six-tiered chronostratigraphic hierarchy of units that are formally defined by a designated GSSP (Global Stage Stratotype and Point) at the base of designated type stages. Henceforth, subseries/subepochs of the Cenozoic are to be denominated by capitalised positional adjectives -Lower/Early, Middle, and Upper/Late - added to the names of the relevant series/epochs.

\section{Introduction}

Indecision and controversy have clouded discussions on the status of subseries/subepochs since the Second International Congress on Stratigraphy (Strati 2015, Graz). This concept, introduced by Charles Lyell (1833) as part of his chronostratigraphic subdivisions of the "Tertiary" (Cenozoic), has played a crucial role in the development of modern chronostratigraphy (Aubry, 2016). Ever since their inception, subepochs have consistently remained a key temporal unit for generalized international communication across disciplines in Earth Sciences, well-recognised in the Cenozoic.

The chronostratigraphic value of the Cenozoic subseries/subepochs has never been questioned, and in scientific publications, including the timescales, their boundaries have been consistently aligned with the boundaries of global stages defined by GSSPs. The point of contention, however, has not been their definition but the question of their status. Should they be recognised as the second rank in a formal six-tiered chronostratigraphic hierarchy from stage to eonothem, or should they remain informal subdivisions of series and epochs in a five-tiered hierarchy? This dilemma was at the heart of the conflicting positions expressed in Head et al. (2017) and Pearson et al. (2017). A temporary resolution to the situation was recommended, so that subcommissions had the freedom to choose between formal and informal status based on individual preference (Finney and Bown, 2017). This led to glaring inconsistency in Cenozoic chronostratigraphy, in that the Subcommission on Quaternary Stratigraphy (SQS) adopted a formal status for subseries whereas the subcommissions on Neogene and Paleogene Stratigraphy (SNS and ISPS) continued to use subseries as informal units despite their obvious ties to stage GSSPs.

The breakthrough that led towards procedural reunification of Cenozoic chronostratigraphy emerged from the simultaneous ratification of subseries/subepochs for the Holocene and Pleistocene series (Aubry and Piller, 2021). The ratification of the Lower/Early, Middle, and Upper/Late Holocene subseries/subepochs corresponding respectively to the Greenlandian, Northgrippian and Meghalayan stages/ ages (Walker et al., 2018, 2019) and the subsequent ratification of the Lower/Early, Middle, and Upper/Late Pleistocene subseries/subepochs corresponding respectively to Gelasian + Calabrian, Chibanian and "Upper" (unnamed) stages/ages (Head et al., 2020) formalised the rank of subseries/subepoch for the Holocene and Pleistocene in the geological timescale. A new question then arose, as to whether the terms subseries/subepoch should be formally defined in the International Stratigraphic Guide. The members of the International Subcommission on Stratigraphic Classification (ISSC) voted a 76\% majority in favour of this inclusion (Aubry et al., 2021).

The International Stratigraphic Guide, first edited by Hedberg (1976) and re-edited by Salvador (1984), is currently under further revision under the auspices of the ISSC, with the objective of updating the Guide in areas where new concepts and/or practices have been introduced. With regard to chronostratigraphic units (Chapter 9) the recent developments described above will require the inclusion of subseries/ subepochs in the chronostratiraphic/geochronologic hierarchy, allowing subcommissions the freedom to choose whether to replace infor- 
mally recognised subdivisions for their systems/periods with formal units of identical definition. The ISSC thus submitted on 19 January 2021 a proposal to the International Commission on Stratigraphy (ICS) for Subseries/subepochs to be accorded the status of formal chronostratigraphic units in a new/revised version of the International Stratigraphic Guide, when published'. On 1 May 2021, the IUGS Executive Committee issued the ratification of the proposal for formal adoption of chronostratigraphical/geochronological unit divisions subseries/subepoch within the International Stratigraphic Guide as approved by the International Commission on Stratigraphy and forwarded to the IUGS EC on 24 March 2021.

The ratification of formal subseries/subepochs has several ramifications. First, subseries/subepochs are no longer mere subdivisions of series/epochs, but as explicitly stated, Subseries can be defined as chronostratigraphic units in a formal rank intermediate between stage and series. They are comprised of one or several consecutive stages, and their boundaries are defined by the GSSPs of the oldest included stage and that of the oldest stage in the subsequent unit. The temporal equivalent of a subseries is a subepoch. Second, the rank is now available for any chronostratigraphic interval for which their use may be beneficial, for instance when the range of a series represents a very long epoch comprised of several stages/ages. Third, following Lyell (1833), Cenozoic subseries/subepochs have been identified using simple positional adjectives applied to the name of the series/epoch, and this tripartite logic would be clearly appropriate for some newly established units, although double positional adjectives would not be suitable. Fourth, the possibility for unification of chronostratigraphic practices in the Cenozoic Erathem (Aubry and Piller, 2021) is now enhanced, which is highly desirable not only in consideration of their common chronostratigraphic history but also to facilitate the dialogue between subcommissions. Fifth, a conceptual double standard, whereby some subseries defined by the GSSPs of their bounding stages at present have informal status based on a preconception that formal subseries could eclipse stages, is now corrected in view of the fact that broadly used chronostratigraphic units which are defined by the same unique criterion - the GSSPs of lower bounding stages — have equal status for the sake of scientific rationality. Finally, the recognition of the formal rank of subseries/subepochs by the IUGS restores harmonious chronostratigraphic practices between the North American Code of Stratigraphic Nomenclature (2005; Aubry et al., 2020) and the Guide (see Piller and Aubry, 2021).

\section{Acknowledgments}

We thank the colleagues with whom the status of the subseries/subepoch has been thoroughly discussed whether during the months that preceded the first round of publications organized by Stan Finney and Paul Bown in 2017, or within the ISSC on the occasion of the vote for inclusion of subseries/subepochs in the Guide, or more recently prior to the ICS vote on the status of subseries in Spring 2021. MPA thanks the commissioners of the NACSN, as well as William A. Berggren, Dennis V. Kent and John Van Couvering for their continued interest and support.

\section{References}

Aubry, M.P., 2016, Cenozoic chronostratigraphic terminology: In defense of formal subseries. Stratigraphy, v. 13, pp. 1-20.

Aubry, M.P., Fluegeman, R., Edwards, L., Pratt, B.R., and Brett, C.E., 2019, North American Commission on Stratigraphic Nomenclature, Note 69-Application for Addition of Subseries/Subepoch to the North American Stratigraphic Code. Stratigraphy, v. 15, pp. 261-263.

Aubry, M.P., Fluegeman, R., Edwards, L., Pratt, B.R., and Brett, C., 2020, North American Commission on Stratigraphic Nomenclature Report 14 - Revision of Articles 73, 81, 82 and Table 2 of the North American Stratigraphic Code to Formalize Subseries and Subepochs. Stratigraphy, v. 17, pp. 315-316.

Aubry, M.P., Head, M.J., Piller, W.E., and Berggren, W.A., 2020, Subseries/Subepochs approved as a formal rank in the International Stratigraphic Guide. Episodes, doi:10.18814/epiiugs/2020/020066

Aubry, M.P., and Piller, W.E., 2021, Untying a Gordian knot: The case of subseries. Newsletters on Stratigraphy, v. 54, pp. 247-250.

Finney, S.C., and Bown, P.R., 2017, The status of subseries/subepochs for the Paleocene to Holocene: Recommendations to authors and editors. Episodes, v. 40, pp. $2-4$.

Head, M.J., Aubry, M.P., Walker, M., Miller, K.G., and Pratt, B. R., 2017, A case for formalizing subseries (subepochs) for the Cenozoic Era. Episodes, v. 40, pp. 22-27.

Head, M.J., Pillans, B., Zalasiewicz, J.A., and the ICS Subcommission on Quaternary Stratigraphy, 2020, Formal ratification of subseries for the Pleistocene Series of the Quaternary System. Episodes, doi:10.18814/ epiiugs/2020/020084

Hedberg, H.D., 1976, International Stratigraphic Guide-A guide to stratigraphic classification, terminology and procedure, New York, John Wiley and sons, $200 \mathrm{pp}$.

Lyell, C., 1833, Principles of Geology. Volume 3. London: John Murray. 398 pp. +160 pp. appendices [1990 reprint by the University of Chicago Press, with a new introduction by M. J. S. Rudwick].

Nomenclature (NACSN), 2005, North American Stratigraphic Code, 2005. American Association of Petroleum Geologists Bulletin, v. 89, pp. $1547-1591$.

Pearson, P.N., Wade, B.S., Backman, J., Raffi, I., and Monechi, I., 2017, Sub-series and sub-epochs are informal units and should continue to be omitted from the International Chronostratigraphic Chart. Episodes, v. 40, pp. 5-7.

Salvador, A., 1984, International Stratigraphic Guide-A guide to stratigraphic classification, terminology and procedure (2nd edition). The Geological Society of America, $214 \mathrm{p}$.

Walker, M., Head, M.J., Berkelhammer, M., Björck, S., Cheng, H., Cwynar, L., Fisher, D., Gkinis, V., Long, A., Lowe, J., Newnham, R., Rasmussen S., and Weiss, H., 2018. Formal ratification of the subdivision of the Holocene Series/Epoch (Quaternary System/Period): two new Global Boundary Stratotype Sections and Points (GSSPs) and three new Stages/Subseries. Episodes, v. 41, pp. 1-11.

Walker, M., Head, M.J., Berkelhammer, M., Björck, S., Cheng, H., Cwynar, L., Fisher, D., Gkinis, V., Long, A., Lowe, J., Newnham, R., Rasmussen, S., and Weiss, H., 2019, Subdividing the Holocene Series/Epoch: formalisation of stages/ages and subseries/subepochs, and designation of GSSPs and auxiliary stratotypes. Journal of Quaternary Science, v. 34, pp. 173-186.

**[E-mail message from IUGS Secretary General Stan Finney to ICS Secretary General Philip Gibbard, 1 May 2021.] 


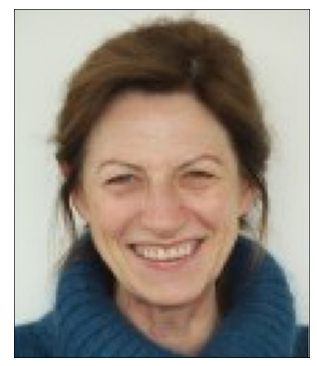

Marie-Pierre Aubry is a Distinguished Professor of Earth Sciences at Rutgers University, USA. She is the Secretary of the International Subcommission on Neogene Stratigraphy (SNS), a voting member of the International Subcommission on Stratigraphic Classification (ISSC) and a Commissioner on the North American Commission on Stratigraphic Nomenclature (NACSN). She was Chair of UNESCO/IUGS IGCP Project 308 (Paleocene/Eocene Boundary Events in Space and Time, 19901995) and the ICS Working Group on the Paleocene/Eocene Boundary (1989-2004). Her scientific interests include Earth Cenozoic history as well as the evolutionary dynamics of the marine plankton. She has edited and contributed to several books in Earth Sciences and she is the author of a multivolume series on Cenozoic Coccolithophores. She is a Fellow of the AAAS.

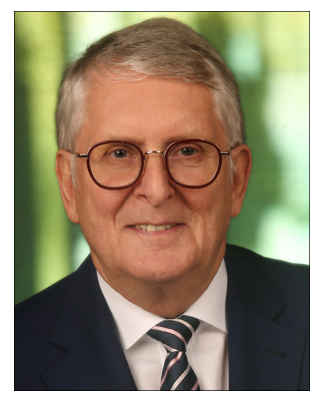

Werner E. Piller is Full Professor Emeritus for Paleontology and Historical Geology at the University of Graz, Austria. He is presently Chair of the International Subcommission on Stratigraphic Classification (ISSC) and voting member of the Subcommission on Neogene Stratigraphy (SNS). From 2004 - 2009 he was Vice-President and from 2009 - 2017 President of the Regional Committee for Mediterranean Neogene Stratigraphy (R.C.M.N.S.) of IUGS. From 2004-2013 he chaired the Austrian National Committee for the International Geoscience Program (IGCP) of UNESCO and since 2013 he is chair of the National Committee for Geo/Hydro-Sciences of the Austrian Federal Ministry of Education, Science and Research (including related UNESCO Programs). 